\title{
SERGIUS HESSEN'S VIRTUE THEORY AND ETHICS OF RESPONSIBILITY
}

\author{
Wojciech Hanuszkiewicz
}

DOI: 10.17846/CL.2021.14.2.158-175

\begin{abstract}
HANUSZKIEWICZ, Wojciech. Sergius Hessen's Virtue Theory and Ethics of Responsibility. Ever since Alasdair MacIntyre published his book After Virtue in 1981, the theory of virtue, stemming primarily from Aristotle, has become an important factor in contemporary ethical discussions. These discussions, however, ignore the platonic theory of virtue. It is in the platonic tradition that Sergius Hessen undertakes his investigations. In Hessen's view, Plato's virtue ethics can be united with the theological theory of cardinal virtues, thus creating one coherent approach. This connection - as long as it maintains its internal, dialectical tension - transforms a traditional concept of virtues focused on the moral perfection of the subject as well as the deontological ethics of Kant, which is based on the universal validity of duty, into the ethics of responsibility, the model of which is presented in Fyodor Dostoyevsky's The Brothers Karamazov. This concept of ethics, rooted deeply in Orthodox Christianity, is noteworthy because it presents, in an innovative way, the issue of the relationship between moral practice and law. In this context, moral practice is understood by Hessen as one of the most important manifestations of human creativity. Hessen's virtue ethics may thus be regarded as the valid opinion that needs to be included in contemporary considerations over the right form of social ethics.
\end{abstract}

Keywords: Sergius Hessen, Fyodor Dostoyevsky, Immanuel Kant, Rafael Santi, Plato, cardinal virtues, theological virtues, Orthodox Christianity, responsibility, creativity, social ethics, moral and law

Sergius Hessen (1887 - 1950), a Russian philosopher and pedagogue who lived and taught in Poland beginning in 1935, presented his theory of virtue, based on solutions presented in Plato's Republic, in a lengthy article entitled Ancient Virtues and Evangelical Virtues (Notes on the Foundations of Ancient and Modern Ethics). ${ }^{1}$ However, this article was not merely a reconstruction of Plato's theory. Although Hessen admits that he considers Plato to be the philosopher who most fully expressed the ethical thought of ancient Greece, only the first part of the study is devoted to the exposition of platonic ethical doctrine. Hessen explains in the second part of the article how the new concept of evangelical values developed by Christianity complements Plato's theory. In this context Hessen conducts an analysis of Raphael's fresco entitled Cardinal and Theological Virtues, which is located on the south wall of the Stanza della Segnatura of the Apostolic Palace in Vatican City. In the third part of this article, the Russian philosopher attempts to show that the manner in which Raphael in his fresco presented the relationships between virtues was by no means random. These relationships trigger a type of dialectical tension similar to that which was already known

This work was written in Polish and Russian during World War II. The Russian version was burned during the Warsaw Uprising, along with many of Hessen's other manuscripts. The Polish version was only published after the death of the Russian philosopher, in a selection of his writings (Hessen 1968b). There is an Italian translation of this text (Hessen 1952). Outside of these two linguistic circles, however, the work is virtually unknown. 
from the platonic theory of virtue. It can also be proven that these dialectical tensions influenced the development of modern ethics, which Hessen presented in his work using the example of the ethical reflections of Kant, Fichte, Schopenhauer, and Nietzsche. In addition to Kant's moral philosophy, a key role in the Russian philosopher's analysis is played by Dostoyevsky's work. Dostoyevsky's last novel, The Brothers Karamazov, can be interpreted, in the context of the platonic and evangelical tradition of virtues, as the most creative and at the same time the pinnacle of both concepts. Based on the literary vision of this novel, Hessen created, as shown below, an original model of the ethics of responsibility. This model captures a new perspective on the interactions between moral practice and the system of legal norms that underpin social life. ${ }^{2}$ The correct apprehension of this relationship is one of the key tasks of moral and social reflection, both then and now. The ancient and Christian concepts of virtue should become, at least in light of Hessen's analysis, not only indispensable starting points for this reflection, but also its destination.

It is only in the Polish literature on Hessen, that the concept of virtues has been more widely analysed and discussed ${ }^{3}$. Researchers pointed out that this issue is, on the one hand, the basis of the philosophical anthropology of the Russian philosopher, and, on the other hand, a model example of dialectical thinking for him. They also remarked that the dialectical dependence which takes place between ancient and Christian virtues leads Hessen to recognize the concept of responsibility as the central category of ethical reflection. On this point, Hessen remains dependent on Dostoyevsky ${ }^{4}$. Nevertheless, scholars have not paid due attention to the role Kant's legacy plays in Hessen's thought in this context. After Hessen they emphasise that the Königsberg philosopher linked, in his moral thought, the ancient virtue of temperance with the Christian virtue of hope. Hessen adds on this point, however, that Kant also develops a critical model of analysis that can be regarded, partly against Kant's intentions, as an adequate approach to the foundations of reflection on legal norms. And it is the dialectical tension between the conceptual representation of legal system and only intuitively experienced moral creativity that constitutes the basic feature of Hessen's model of ethics of responsibility.

In order for all the issues raised here to be addressed accurately, the article was divided into two parts. The first part (I) presents the platonic theory of civic (cardinal) virtues and its subsequent modification resulting from the development of the concept of theological (evangelical) virtues

2 In this context, two of Hessen's works dedicated to Dostoyevsky remain particularly relevant. The first, The Idea of Moral Good in the Novel 'The Brothers Karamazov': comments on Dostoyevsky's ethics was originally published in Russian language (Hessen 1928), then in German (Hessen 1929a), and later in a Polish translation (Hessen 1929b). (I use the Russian and Polish versions).The second work is an extensive paper entitled The Battle of Utopia and Autonomy of Good in the View of Dostoyevsky and Solovyov published originally in German (Hessen 1929b), then in French (Hessen 1930) and Russian (Hessen 1931). The existing Polish translation (Hessen 1968a) is a translation of the Russian version. (I use these two last editions). The Russian texts (Hessen 1928; Hessen 1931) are available on-line: http:// emigrantika.imli.ru/news/7-sovremen [accessed: 04.03.2021]. Another important work for the issue presented here is an article entitled Law and Morality (Hessen 1968c), which was completed during the last days of World War II and written in Polish. There is an Italian translation (Hessen 1958).

3 Regarding studies in Polish, the fullest discussion of this work can be found in the Zbigniew Wieczorek's dissertation (Wieczorek 2005, 40-42, 80-102). Compare also: Kukuła 1997.

4 In a very interesting way, the problem of responsibility and the concept of dialectics in Hessen's philosophical and pedagogical thought were discussed by Andrea Folkierska in her book (Folkierska 2005). The author points to the convergence of Hessen's project with the thought of Hannah Arendt. The weak point of this interpretation, however, is the complete omission of Hessen's relationship with Dostoyevsky and the entire Russian philosophical tradition. 
in Christian thought. The second part (II) focuses on the question of the reception of both of these concepts in modern philosophy.

While presenting the platonic theory of virtue, Hessen focuses on the well-known fragments of Plato's Republic devoted to the order of social life that reflects in its structure the constitution of the human soul. ${ }^{5}$ The three social classes include: workers (poietai), ${ }^{6}$ guardians/soldiers (fylakes), and rulers (kyrioi). These three have their counterparts in the three parts of the soul: appetitive (epithymetikon), volitional/'spirited' (thymoeides), and rational (to logistikon). ${ }^{7}$ Both the social classes and the parts of the soul are ranked from the lowest to the highest. The workers produce economic goods; the guardians are in charge of the state's defence and are the executive power; and the rulers run the affairs of the entire state. The lowest part of the soul, just like the economic state in the state, "is the embodiment in the soul of the element of plurality" (Hessen 1868b, 200); for sensual desire and passions are directed toward the multiplicity of external objects. Desire pulls the appetitive soul in all directions; for this reason it is close to disintegration. The virtue that secures its integrity is temperance (sophrosyne). The second part of the soul 'is the will understood as the ability to decide' (Hessen 1868b, 201). The role of this part is to keep feelings in order and to prevent them from flaring up into passions. This part of the soul therefore performs the same managing and executive function as the guardians do with respect to the state. The virtue of this part of the soul is courage (andreia). The ability of reasoning is the highest part of the soul. It gives a constant direction to all human activity and protects the unity of human personality. The virtue of this part of humans is wisdom (sophia or phronesis), which is, as the Russian philosopher states, "the intuition of the ultimate goals of man's life and man's destiny" (Hessen 1968b, 201). The rational soul therefore has the same overriding role in relation to the other parts of the soul as the rulers, identified by Plato with the philosophers, have in relation to the other social classes in the state. If each part of the soul manages to maintain a virtue that is assigned to it, then the soul of human is characterized by justice (dikaiosyne). Similarly, in a state, if each social class cultivates a virtue that is assigned to it, then the whole state will be righteous. These issues are well known. Hessen presents them in the form of a figure:

$\begin{array}{lllll}\text { State } & \text { Justice } & & \text { Individual } \\ \text { Rulers } & \longleftarrow & \text { Wisdom } & \text { Reason } \\ \text { Guardians } & \longleftarrow & \text { Courage } & \text { Will } \\ \text { Workers } & \longleftarrow & \text { Temperance } & \longrightarrow & \text { Appetite }\end{array}$

5 This issue is discussed in Book IV of the dialogue. There are many translations of it into English. I use Allan Blooms translation (Plato 1991) and the Greek text (Plato 1903) available on the Perseus website: https:// www.perseus.tufts.edu/hopper/text?doc=Perseus\%3atext\%3a1999.01.0167 [accessed: 04.03.2021].

6 In this way, i. e., as the 'poieitai', the lowest social group is described by Hessen (1968b, 207), but Plato most often uses the term 'demiurgoi' (for example: Politeia 369d, 371a).

7 The lowest layer of the soul is, in other words, sensuality, the middle layer is the will, and the highest layer is the reason. In defining the middle layer as the will, Hessen follows the platonic theory of virtue as the basis of the analyses presented in Paul Natorp's Sozialpädagogik (Natorp 1904, 107-135, especially: 118-119). The word 'thymos', used in this context by Plato, is usually translated into English as 'spirit' or 'spiritedness'. So does Bloom, though he points out that the best term to use would be 'heart' (Plato, 1991: 448; footnote 33 to passus: Politeia, 375b). 
Plato's theory of virtue is of interest to the Russian philosopher primarily because of the dialectical tension that arises between individual virtues. This tension can be twofold in nature. It may be characterized, according to Hegel's much later distinction, by good or bad dialectics. The analyses presented in The Republic show that each of Plato's cardinal virtues can properly fulfil its function only and so far as it is infiltrated by the virtue, which, in the hierarchical system of virtues, is situated above it. Thus, temperance as a virtue of the lowest, appetite part of the soul does not involve those desires and passions being mechanically suppressed - this kind of suppression is characteristic of various forms of asceticism - but it means that desires and passions are creatively reorganized, and because of that, they are transformed and raised "to the higher plane of being". (Hessen 1968b, 204). But for this transformation to be possible, desires and passions must be subject to a higher principle giving unity (a certain direction) to their movement. The task of moderating passions and sensual desires in such a way cannot succeed if the will, which is already the higher part of the soul, lacks perseverance in the pursuit of one goal. Therefore, the virtue of temperance, if it is not to become a caricature of itself, i. e., an asceticism, must be infiltrated by the higher virtue of courage.

Courage also can take two forms. Perseverance in the pursuit of a goal, i. e., characteristic for courage, can turn into purely mechanical audacity and bravado, involving the pursuit of a predetermined goal at all costs, regardless of the circumstances and the scale of the risk. However, properly understood courage never allows for the mechanical hegemony of one finite goal over all other goals because it seeks to harmonize many different goals of human activity "into one organic whole" (Hessen 1968b, 207-208). This harmony is, by its very nature, possible if the virtue of courage is infiltrated by a higher virtue of wisdom that is based on the intuition of man's ultimate goals. Therefore, the virtue of courage presents for a human a new task, "the task of understanding the hierarchy of values" (Hessen 1968b, 208). And this is already the task of the virtue of wisdom, which belongs to the highest part of the soul, that is, to reason. This virtue is based on the intuition of good, which transcends all being (epekeina tes ousias). If wisdom lacks this intuition, it breaks away from courage and temperance, turning into its caricature, i. e., into 'omniscient' sophistry. The latter is characterized by an internal contradiction of thought and a lack of individual beliefs. Each of Plato's virtues remains itself, that is, it does not transform into its own imitation (imperfection), only if it occupies its proper place in the hierarchy of virtues, through which it forms a structural unity with the other virtues. Hessen writes on the subject:

In this way, each virtue points to the next virtue, as if each virtue was falling into the next one as its tributary, as its organic moment. Thus, in essence there is only one virtue: individual virtues are only moments ("parts") of the same one virtue, which unites them all in a harmonious synthesis. This fullness of virtue - the synthesis of all its individual moments - Plato sees in justice. In application to the individual, justice means the harmonious fusion of three parts of the soul, each of which, without going beyond its limits, performs its proper function, so that the entire personality of man fulfils its destiny. In application to the state, justice means internal peace and consent between the particular classes, each of which, in submission to the higher one, fulfils its proper function and receives in return fully what it is entitled to receive (Hessen 1968b, 208).

Justice understood in this way also has its imitation. When justice breaks away from wisdom closely associated with courage and temperance, it becomes a seeking sophistry meddlesomeness 
(polypragmosyne). ${ }^{8}$ It involves intrusive interfering with someone else's affairs. It does not seek good, but instead seeks to gain power over people, ultimately leading to the loss of man's vocation and the loss of man's own personality. This type of situation can only be prevented when the relationships between the individual virtues regarded as moments of one coherent entity are properly captured. A summary of the entire discussion devoted to the platonic concept of virtues is presented by the Russian philosopher in the form of a diagram (Hessen 1968b, 209):

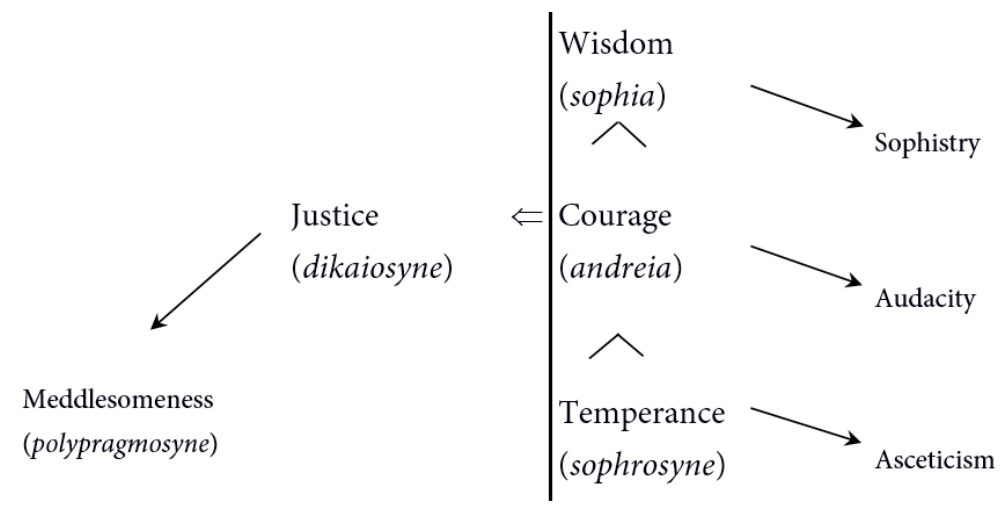

This coherent unity remains harmonious only to the extent that its individual moments remain in a dialectical relation, which is the case when the higher virtue "shines" (Hessen 1968b, 210) through the lower one, thus preventing the lower virtue from becoming its caricature:

The higher virtue is therefore not so much the unity of the subordinate virtues, but rather their "fullness", being their refinement and, at the same time, a condition of their fulfilment (Hessen 1968b, 210).

Thus, the relationship between virtues remains mutual. While the higher virtue remains a principle for the lower virtue, without which the latter could not be fully formed, the lower virtue is an indelible 'moment' of the higher virtue. Temperance is that kind of moment for courage. Courage (in the company with temperance) is an indispensable "skeleton" (Hessen 1968b, 210) for wisdom. Hessen summarizes the platonic dialectic model defining the relations between the individual virtues as follows:

Every virtue, in order to remain itself, must be simultaneously something else (temperance must be courage, and courage must be wisdom), i. e. it must be "unity of one and the other". From this platonic concept [...] comes not only Aristotle's doctrine of virtues as "means" (mesotes) between the two extremes of degeneration, but also the later doctrine of Nicolaus Cusanus of the unity as "coincidence" of opposites. The study of the higher principle understood as fullness of lower, subordinated ideas is the germ of the theory of the fullness (pleroma) of Plotinus, which, in turn become inspiration for Hegel's dialectical method. Plato's ambiguous term, "meros" (part), is, in this case, replaced by the new term: "moment" (das Moment). This term defines the lower idea in relation to the higher one, which is understood as the fullness of its subordinate moments; it is their "synthesis".

8 The term 'polypragmosyne' appears in a following fragment: Polytheia, 434b; elsewhere in this dialogue (444b) Plato also uses the word 'allotriopragmosyne'. 
Such features of Hegelian dialectics as the concept that the lower idea is "abolished", but also preserved in the higher one (both meanings of the word "aufheben"), that lower idea is saved from being distorted into its "caricature", or its "imitation" only by being elevated to a higher level - had already been present in description of the mutual relationship between ideas in Plato's doctrine of virtue (Hessen 1968b, 212).

While outlining the reception of Plato's dialectics this way, Hessen also emphasizes that in "ancient post-platonic ethics, the theory of virtue loses its meaning" (Hessen 1968b, 216). Although Aristotle still paid a lot of attention to it, even he did not develop a cohesive system of virtues. The concept of virtue is no longer an idea in his understanding, but it becomes a disposition of the soul (hexis, habitus). The virtues, as a subject of consideration, became less important while the issue of eudaimonia, that is, happiness resulting from a fulfilled life, became a main topic. This remark may seem controversial for two reasons: first, the problem of eudaimonia remains a key issue of Plato's virtue ethics and Aristotle, in his considerations on this issue, clearly follows Plato's footsteps; secondly, the problem of virtues is a central issue in Aristotelian ethics. However, Hessen's observation may be justified by the important difference that appears in the above context between the two Greek philosophers. For Plato, eudaimonia and the theoretical contemplation associated with it means the full realization of virtues, while for Aristotle, the civic virtues realized in the political life of human being are fundamentally different from the theoretical contemplation through which the fullness of eudaimonia can be achieved. A political life based on civic virtues is primarily intended to create social conditions in which individuals capable of contemplation (philosophers) can indulge purely theoretical life. In this view, a political life, which is based on civic virtue, remains indispensable, but it is fundamentally different from theoretical life and has, in Aristotle's view, a lower rank compare to theoretical life. ${ }^{9}$ Similarly, the ethical issues of eudaimonia and civic virtues were addressed in the Hellenistic schools (Cynicism, Epicureanism, Stoicism). One exception here is Plotinus, who places the theory of virtues at the heart of his ethical reflection. He devotes one of his most important treatises to virtue (Enneads, I, 2). ${ }^{10}$ However, Plotinus' analysis indicated that all of classical Greek virtues had already largely become obsolete. Plotinus' work indicated an understanding that there is a clear distinction between traditional ancient Greek 'civic virtues' (politikai arietai) and the 'higher' virtues (meizones), referred to as 'purification' (katharsis). These virtues, as Hessen writes:

belong no longer to the soul of a human, but to the intellect (nous), and even to the highest principle. These higher virtues transcend human realm - for the soul pursues them in the process of becoming godlike (theosis) - and they transform the purely human virtues of temperance, courage and justice (Hessen 1968b, 217).

Plotinus' distinction between lower and higher virtues prepared the ground for the division (shaped in Christian tradition) of platonic (at its source) cardinal virtues such as temperance, courage, wisdom, justice and the theological virtues of faith, hope and love originating with the New Testament. Although this distinction is evident already in the work of St. Augustine, the Fathers of the Church did not pay special attention to the problem of the interrelationship between these two types of virtues. Nevertheless, Christianity brings to ethical thought an innovation by emphasizing the importance of the individual fate of each individual human being. Ancient ethics

9 Compare: Grant 1885, 215; Guthrie 1981, 390-396.

10 This Enneada is entitled Peri areton (About virtues). The Greek text (Plotinus 1856) is available online: https://web.archive.org/web/20071006090521/http://plotin.lotophages.org/ [accessed: 04.03.2021]. 
always recognized the individual as a citizen of the state - the cardinal virtues depicted by Plato are civic virtues. Thus, in such ethics the goal was the achievement of political order. St. Paul, on the other hand, emphasizes in his Epistles, which are the oldest texts in the books of the New Testament, that the Christian God is the God of all people regardless of nationality, citizenship or language. When the primary concern of ethics becomes the care for individual fate of a human, the political issues become of a secondary importance. The belief in God, in Paul's thought, is not to be identified with the purely theoretical attitude of the sage, which Plotinus presented in the Enneads. The Christian belief in God is not some theoretical contemplation, but a personal and intimate relationship that is based on full engagement. This engagement is most fully expressed in a particular life's practise such as love of one's neighbour (agape, caritas). It also allows one to hope that it is through faith and love that one will attain salvation.

In this context, the question arises as to how much the civic virtues known to the ancient world are needed by Christians who practice evangelical virtues. Hessen points out that as early as in the work of St. Augustine, who was not at all sympathetic to the ancient theory of virtues, one can find statements not so much disqualifying the meaning of civic virtues, but emphasizing the need to transform them through the evangelical virtues (Hessen 1968b, 218) ${ }^{11}$ However, this problem gained attention, as the Russian philosopher points out, only during the Renaissance, when studies of Plato's works were renewed. The greatest expression of it has been found not in the philosophical treatises of the period, but in a fresco by Raphael commissioned by Pope Julius II. For many years, this fresco was interpreted and titled as The Three Virtues. ${ }^{12}$ It was believed that it depicted three allegorical figures of temperance, courage, and wisdom. The work itself is described by Hessen as follows:

Only three virtues are depicted in the fresco: the figure to the right of the viewer, holding the reins - the abstinence emblem, symbolizes temperance; the figure to the left, having as its emblem a lion's head, is a symbol of courage; the figure in the middle, placed slightly higher than the previous two, is wisdom (the head of Medusa on her chest is a traditional emblem of wisdom, that decorate almost all ancient images of Athena). Justice does not have a separate appearance in the fresco: it is, according to Plato's doctrine, a synthesis, or the fullness of the other virtues. Its representation as a symbol of the unity [...] is in the ceiling medallion above the fresco (Hessen 1968b, 220-221).

A breakthrough in the interpretation of this fresco was made by Edgar Wind (1937-1938) when he noticed the three putti, which until then had only been attributed with a decorative role. Using an appropriate comparative material, this researcher showed that putti symbolize the three theological virtues (faith, hope, and love) ${ }^{13}$ Each figure personifying one of the cardinal virtues is also accompanied by one putto. Hessen writes on the subject as follows:

${ }_{11}$ In making the above remark, the Russian philosopher refers (Hessen 1968b, 281, footnote) to one of Augustine's dialogues (De vita beata, IV, 35). This reference is incorrect. However, this does not change the fact that in the works of the author of De Civitate Dei one can indeed come across statements emphasizing the role of Christian love in transforming pagan virtues (De Moribus Ecclesiae Catholicae, XV, 25), as well as remarks referring to the Epistles of St. Paul indicating the close connection between justice and faith (De Civitate Dei, IV, 20). St. Augustine's works are quoted according to the edition of S. Aurelia Augustini Opera Omnia. Patrologiae Latinae Elenchus (Migne 1841 - 1865), available online: http://www. augustinus.it/latino/index.htm [accessed: 04.03.2021].

12 This is the title Hessen used in his article. Nowadays, the fresco is usually given the title: Cardinal and Theological Virtues.

13 In the first half of the 1940s, the period in which Hessen wrote his article, this interpretation was an 
In this fresco, the ancient or civic virtues are complemented and refined by the evangelical virtues: temperance by hope, courage by the love of one's neighbour, and wisdom by faith. The basis of the artist's vision is Plato's theory. The evangelical virtues do not remove civic virtues, but merely transform them, bringing them to life with a new Christian spirit (Hessen 1968b, 222).

Hessen considers this interrelation of cardinal and theological virtues as the most important contribution of renaissance Platonism to the modern moral reflection. In the last, philosophically most interesting part of his paper, Hessen attempts to interpret the development of modern ethics from this new perspective depicted in Raphael's fresco.

\section{II}

To study this issue more thoroughly, Russian philosopher proposes tracing the history of modern ethics, starting with Kant's practical philosophy. Kant's thought is important for two reasons. First, he created an autonomous ethics, that is, a theory of ethics independent of religious assumptions. Secondly, according to Hessen, the concept of moral autonomy developed by Kant does not contradict the most critical ideas of Christian theology; in contrast, it directly stems from them.

Seeking fully autonomous foundations for morality, i. e., a foundation independent of religious and metaphysical assumptions, Kant considered the principle of duty (Gesetz der Pflicht) to be the basis of his practical philosophy. The principle of duty finds its proper expression in the categorical imperative (Hessen 1968b, 238-240). In its basic formula, which appears in the Groundwork of the Metaphysics of Morals, this imperative is as follows: "act only in accordance with that maxim through which you can at the same time will that it become a universal law" (Kant 1999, 73 [IV 421] ${ }^{14}$ ). The categorical imperative does not say which maxims of moral action we should use. It is up to us to choose our maxims based on the situation and the problems we face. The categorical imperative only helps us to resolve whether the maxims we choose are suitable for the rules of moral conduct. They are suitable when they can be given the validity of general laws applicable in the same way to all rational beings. A maxim can therefore become duty when it is completely selfless; that is, when it does not take into account our individual inclinations and desires, but instead takes into account a community order that imposes the same obligations on all. Duties must not only be selfless but must also be completely autonomous. Kant argues that the categorical imperative regarded as the principal condition of autonomy can therefore be expressed "as [...] the idea of the will of every rational being as a will giving universal law" (Kant 1999, 81 [IV 431]). In this view, universal law plays a key role.

The philosopher from Königsberg understood that universal law, being a full expression of the autonomy of all moral entities, remained as an idea which in actual moral practice can never be fully realized. This idea, however, is not some idle invention out of touch with the actual moral

important novum. It is now widely accepted. Compare, for example, the Wikipedia article Cardinal and Theological Virtues (Raphael), which also features good quality photos of both the fresco itself and the medallion placed above it representing justice. Online address: https://en.wikipedia.org/wiki/ Cardinal_and_Theological_Virtues_(Raphael).

Raphael's fresco is also possible to find in the virtual gallery of the Musei Vaticani:

https://www.museivaticani.va/content/museivaticani/en/collezioni/musei/stanze-di-raffaello/stanzadella-segnatura/virtu-cardinali-e-teologali-e-la-legge.html [accessed: 04.03.2021].

14 The numbers in square brackets refer to the collective edition of Kant's works, published by the Prussian Academy of Sciences (Kant 1903ff). The Roman number means volume, the Arabic number means page. 
practice. Actual moral practice assumes this idea as its own condition of possibility..$^{15}$ At the same time, it is an idea that in relation to all moral actions can be thought only negatively, i. e., as such a goal which gives us an opportunity to see how we should not act rather than allowing us to formulate a specific maxim of action. In the above 'negative' perspective, Kant sees morality as a constant struggle against all factors that threaten the autonomy of the subject. ${ }^{16}$ These factors cause a subject's heteronomy to be understood as dependence on external instances, above all dependence on sensory stimuli (desires, emotions, feelings, habits).

Morality understood in such a way finds its fullest expression in self-discipline (controlling one's sensory tendencies), hence it represents, as Hessen emphasises, the fullest realization of virtue of temperance (sophrosyne). The only thing a moral subject really needs, according to Kant, is a purely practical belief in the ultimate success of one's own efforts. Only then can the moral actions of a subject be considered as reasonable actions, i. e., actions which are ultimately worth taking. The idea of autonomy itself, the idea of full freedom of the subject, being, as mentioned above, a negative idea, does not solve this problem. It only allows us to understand that autonomy has not yet been fully achieved by human beings. Moreover, the negativity of this idea also means that we do not have any 'positive' knowledge of how we could fully implement this autonomy. However, its implementation must be seen as feasible by the subject. In order for this to happen, we must therefore assume, at least as a postulate, the possibility of infinite moral improvement of each individual. This is not a theoretical assumption but a practical one. We don't know if it is true; we can only believe it.

In order for our moral action to be reasonable, something else needs to be assumed. Ultimately, our moral actions need to lead to the highest good. The totality of the highest good means not only the moral perfection (autonomy) of the subjects but also means their full happiness. This assumes, again in the form of a postulate, the existence of an instance that can ensure this happiness. As before, this postulate is not theoretical. First, we do not know whether such an instance (the highest being, God) exists at all. Secondly, we do not have knowledge of what happiness itself would look like. All we know is that every human being desires this happiness. Both possibilities the former entails a belief in the immortality of the soul, the latter a belief in God as the guarantor of happiness which cannot be achieved by humans on their own - Kant calls the postulates of practical reason.

It is at this point that Kant's moral reflection presents, as Hessen points it out, a clear link between the cardinal virtue of temperance and the Christian virtue of hope. The practical belief in the immortality of the soul and in God allows a human to hope that the moral struggle for self-discipline, or temperance, will ultimately make sense. However, this hope is limited to the practice itself and is expressed only in this practice. Only a person who acts, and while acting with self-discipline courageously fulfils one's own duty, can place one's hope in God. Hessen (1968b, 243) cites in this context Kant's statement from Religion within the Boundaries of Mere Reason:

15 The idea of autonomy is considered interchangeable with the idea of freedom, which we become aware of and realize through moral law. In this context, Kant understands freedom as the ratio essendi (condition of existence) of moral law, and moral law as the ratio cognoscendi (condition of cognition) of freedom. The idea of autonomy, homogeneous with the positive notion of freedom - the freedom to autonomously establish rules of moral conduct - must be distinguished from purely formal freedom in negative meaning, which Kant understands as mere independence from sensory stimuli. (Kant 1999, 140, 166 [V 5, V 33]). Positive freedom assumes negative freedom as its condition but is not identical with it.

16 Kant pointed this out expressis verbis in his Metaphysics of Morals (Kant 1999, 533 [VI 405]), which also has been noticed by Hessen (1968b, 240, footnote). 
Each must [...] so conduct himself as if everything depended on him. Only on this condition may he hope that a higher wisdom will provide the fulfilment of his well-intentioned effort (Kant 2001, 133 [VI 100-101]).

In other words, a person only has the right to hope that his or her moral action - along with the action the person's life as a whole - will prove to be meaningful when he or she acts at all. The person needs act in such a way, as if in every particular situation he or she has to deal with, everything depends solely on him or her. Up to this point, while analysing Kant's thought, Hessen did not have any objections. However, if we assume that everything in our action depends on us and only us, then - as Hessen proves in his The Law and Morality - the famous formula of the categorical imperative that dictates acting in accordance only with such a maxim, in respect of which the acting subject wish to become a universal law, should take the form of: "act in such a way that everyone in your place at this unique moment will do the same" (Hessen 1968c, 303). Only such a formulation is able to convey the strictly individual character of the act, as well as the fully individual, (though at the same time, having universal characteristics) hope associated with this act and expressed in it. But that means, concludes the Russian philosopher, the same thing as:

"act as only you (and no one else) can in this individual situation", because neither the place, nor the moment, nor the whole particular situation will ever happen again. Hence Fichte correctly inferred that the formulas of categorical imperatives may take another forms: "be irreplaceable in your place" or "you can (i. e. only you in this individual situation and unique moment can), so you should" (Hessen 1968c, 303-304).

In this interpretation, Fichte appears as the creator of concrete ethics. ${ }^{17}$ These ethics realize the assumptions immanent in Kant's project, though not fully expressed by Kant himself. These ethics satisfy the universalization requirement imposed on specific maxims (rules of action) by the categorical imperative. However, the requirement of universalization here refers not to the rules of operation itself, but to the fully individual way of acting in a particular unique situation. This way of action cannot be captured in the form of universally applicable rules that can be expressed discursively, i. e., by means of concepts. With regard to fully individualized moral actions, we can only have a purely practical intuition, that is, intuition of the will (Hessen 1968c, 299), to use the term Hessen derived from the works of Georges Gurvitsch. ${ }^{18}$ However, this does not change the fact that the value of universality invariably inheres in moral action. However, it inheres in it in such a way as we talk about the value of universality in relation to a work of art. As Hessen expresses it:

It was Kant's mistake thathe could nothaveimagined this universalvalue (Allgeneingültigkeit), other than in the form of repetitive and average generality (Allgemeinheit). Meanwhile, completely individual (that is unique and irreplaceable) artwork can have universal value. This is true, for example, in case of any work of art, or even a creative reproduction of that work by a virtuoso or an actor. This is also the truth in the case of a moral act, as well as a corresponding moral duty which this moral act fulfils. The moral duty has a uniquely individual character. This is why it cannot be contained in the ready-made standard

17 In his argument, Hessen follows Fichte's interpretation of the practical philosophy as presented by Georges Gurvitsch in Fichtes System der konkreten Ethik (Gurvitsch 1924).

18 In addition to the aforementioned work on Fichte, two other publications by this author remain relevant in this context: Idée du droit social (Gurvitsch 1932) and Eléments de sociologie juridique (Gurvitsch 1940). 
formulas that use concepts of general (that is repetitive) meaning, but rather it can be expressed in regulation that have a character of guidance, model, or example. Capturing the moral duty is a matter of "vision of the heart", "intuition of the will", which sometimes requires instant action (when there is a sudden need). It is not a matter of "common sense" (Hessen 1968c, 304-305).

Kant's mistake, therefore, is to try to establish a purely discursive basis for morality, which precludes de facto the possibility of capturing both the individuality of the subject performing moral actions as well as the uniqueness of the situational context in which these actions themselves take place. Moral entities are granted the value of being a person which, as Kant stresses that it is an absolute value, i. e., the value that is not exchangeable to any other value. Yet the concept of a person remains a legal concept in Kant's theory. A moral subject is a legal person, and therefore it should be (like the law itself, which the subject autonomously confers on itself and, at the same time, is a governed by) the object of respect. The living personality and individuality of a person, which as such can manifest itself as the object of love of one's neighbour, are here largely ignored. Priority is given to the legal order. A person is entitled to be respected precisely because he or she is part of that order. For this reason, Kant's morality of temperance and hope is transformed into an abstract rigorism of legal duty, detached from the particular, individual human life.

This self-contained moral rigorism became, as Hessen points it out, the starting point for Nietzsche's philosophy. The author of Thus spoke Zarathustra contrasted such a vision of morality with that, the foundation of which is in creativity. The dignified master morality - contrasted with poor morality of slave - consists in creating and realizing the values, rather than submitting to some legal order. However, Nietzsche failed to completely liberate his philosophy from the mistake of rigorism. More harshly than Kant, Nietzsche refused any positive meaning in the love of one's neighbour, which he contrasted with the love of the distant. It is a love for the superman ideal to which man is to strive by constantly overcoming himself. In turn, the Christian concept of love is completely negated and considered the basis of the morality of slave. The slave mentality is not able to bear, as Hessen writes:

the clear and cold air of the mountain peaks, the habitat of a brave and pure hero who willingly took the hard road of constantly overcoming himself to achieve, shining in the distance future, the ideal of superman. The Christian concept of the love of one's neighbour (Caritas) Nietzsche clearly contrasted with the heroic "love of the distant" (Eros) as the only worthy model of love for a being who is "constantly overcoming itself" (Hessen 1968b, 248).

Nietzsche's major attack on the concept of neighbourly love and the resulting morality is not entirely unfounded. The author of Thus spoke Zarathustra identifies the love of one's neighbour with the feeling of pity. For Nietzsche, the polemic with Christian morality is also largely a polemic with Schopenhauer. What is most important in this context, however, is that Schopenhauer's depiction of love to one's neighbour as pity was by no means an arbitrary conception. It remains characteristic of modern middle class morality, in which the idea of humanitarianism became quite prominent. This idea, as Hessen points it out, is, however, a distortion of the evangelical love of one's neighbour. ${ }^{19}$ In humanitarianism there is a complete separation of the theological virtue of love from the virtue of faith:

19 See also: Scheler 1972. Hessen does not refer to Scheler's work in this context (its first edition appeared in 1912), but the arguments of the two authors are quite similar on this point. 
Love, detached from actual faith in god and not infiltrated by it, cannot stand as true love, but distorts itself into self-permissive compassion or even pity that finds human repugnant (Hessen 1968b, 252).

The virtue of faith is placed over the virtue of love and it conditions the proper realization of the latter. To properly present and analyse this issue, Hessen reaches to Dostoyevsky's literary work, in which he finds a unique complement to the Kantian ethics of temperance and hope. This complement can be derived primarily from The Brothers Karamazov. According to the interpretation proposed by Hessen, the three sons of Fyodor Pavlovich Karamazov embody three forms - or three degrees - of good: Dmitri is the personification of natural goodness, which is expressed in reactions and actions performed without reflection; Ivan represents autonomous good, which is already the subject of intellectual thought; Alyosha is the embodiment of the supreme form of goodness, i. e., love (Hessen 1929a). Love is not a contradiction of either natural or autonomous good. Love does not question the fact that the natural basis of ethics are human natural reflexes, or the fact that ethical action requires a subject's autonomous reflection on what are, in a given situation, his moral duties. Both forms of good are preserved in love, but in love they are devoid of their limitations. Only through this can they be fully realized without turning into their own distortions. Love, however, cannot be regarded as just a feeling. With regards to moral practice, it means above all else a certain way of acting. In Dostoevsky's novel, this issue is emphasized by the starets Zosima, who distinguished between dreamy (sentimental) love and active love. In conversation with the 'woman of little faith' (The Brothers Karamazov, book II, chapter IV), he stated:

love in action is a harsh and dreadful thing compared with love in dreams. Love in dreams is greedy for immediate action, rapidly performed and in the sight of all. Men will even give their lives if only the ordeal does not last long but is soon over, with all looking on and applauding as though on the stage. But active love is labor and fortitude, and for some people too, perhaps, a complete science (Dostoyevsky 2009, 58).

Hessen concludes stating that active love is courageous and persistent in its essence. It does not abrogate the meaning of moral duty, but merely enhances it and gives it fullness (Hessen 1968b, 251). Active love also includes hope as its moment. The starets Zosima highlights this point:

And let not the sin of men confound you in your doings. Fear not that it will wear away your work and hinder its being accomplished. Do not say, "Sin is mighty, wickedness is mighty, evil environment is mighty, and we are lonely and helpless, and evil environment is wearing us away and hindering our good work from being done". Fly from that dejection, children! There is only one means of salvation, then take yourself and make yourself responsible for all men's sins, that is the truth, you know, friends, for as soon as you sincerely make yourself responsible for everything and for all men, you will see at once that it is really so, and that you are to blame for every one and for all things. But throwing your own indolence and impotence on others you will end by sharing the pride of Satan and murmuring against God (Dostoyevsky 2009, 356).

A human is able to endure being in active love only if he or she can hope that the next actions taken against all possible odds - will not ultimately prove fruitless. In this context, Zosima is advised to take responsibility and take the blame for all the sins and weaknesses of every human being without 
exception, which may seem somewhat surprising. For Zosima, it is the only salvation for us and for the world we live in. The reverse approach - in which one blames others for one's indolence and inability to act (thus one's own sinfulness) - is a manifestation of Satan's pride and a murmur against God. Hessen points out that in this passage Dostoevsky, when talking about indolence and inability to act, uses the Russian word 'uninie', which is equivalent to the Greek (and later Latin) term meaning acedia. The word 'uninie' should, according to Hessen, be understood as lifelessness (laziness) of the heart. The Russian philosopher emphasizes that in the tradition of Eastern Christianity, it is one of the primary deadly sins of weakening of faith understood as an active and personal contact with God. Therefore, if love is to remain a living, active and creative love, if, in other words, a person is to avoid the lifelessness of the heart (acedia), then he or she must find the ultimate basis of a relationship to one's self and to the world in active faith in God.

In this way, Hessen manages to demonstrate the validity of all the relationships between individual virtues that appear in Raphael's fresco. The theological virtue of faith, together with the civic virtue of wisdom, occupies a central place in this fresco, and it is the virtue of faith that is the culmination and at the same time the final condition for the proper realization of all the other virtues (hope and temperance as well as love and courage). If Hessen's interpretation is to be regarded as valid, then the question of how faith is able to infiltrate or shine through - to use the metaphor utilized by the Russian philosopher - the virtue of wisdom and elevate it to a higher level, needs to be answered. In examining the relationship between faith and wisdom, Hessen continues to follow Dostoevsky's literary vision. He points out that active, courageous love is the only way that can lead a human to an active faith in god. This faith has nothing to do with knowledge, dogmas, or any theoretical act of cognition. It is expressed only through action. In this sense, it excludes all theoretical wisdom and all theoretical (conceptual) knowledge. In the aforementioned conversation with a woman of little faith who, as she herself confesses, cannot believe in God, the starets Zosima advises:

Strive to love your neighbor actively and indefatigably. In as far as you advance in love you will grow surer of the reality of God and of the immortality of your soul (Dostoyevsky $2009,56) .^{20}$

Faith is here understood as the culmination of the active love of one's neighbour. Interestingly, Hessen presents a similar thesis with regards to the purely rational and purely practical faith that appears in the Kantian model of morality. In this model:

The man approaches God, or rather God reveals himself to a man only by way of moral action, not by way of ethical knowledge (Hessen 1968b, 244).

Of course, the allegations made by Hessen against Kant's project of practical philosophy remain valid. A purely practical faith in Kant's understanding is based, however, solely on moral practice, and it is this characteristic that brings it closer to the concept outlined by Dostoyevsky. This characteristic makes possible to capture in an entirely new way Kant's key problem of autonomy. From Hessen's perspective, this problem cannot be limited to the autonomy of the moral law itself because we are dealing with a much broader autonomy of good. In this context, comments made by Hessen in his dissertation The Battle of Utopia and Autonomy of Good in the View of Fyodor Dostoyevsky and Vladimir Solovyov remains relevant. The Russian philosopher argues in it that the problem of the autonomy of the good according to the vision outlined in

20 All three passages cited above from Dostoevsky's novel are quoted in extenso by Hessen (1968b). 
The Brothers Karamazov can be expressed in the thesis, 'The good comes from God' (Hessen 1931, 286; Hessen 1968a, 128). The phrase, however, must be properly understood. Hessen writes:

Good as a necessary consequence arising from the existence of god and the immortality of the soul would be an enforced good, whereas it should, by the free choice of human, reside in one's heart. [...] The belief in the existence of God and the immortality of the soul is a consequence of active love, not its basis. This thought is constantly repeated by the starets Zosima. He claims that even an atheist who with his reason denies God and immortality of soul can return to God and see him through acts of mercy. ${ }^{21}$ Good as an active love of one's neighbour is independent of knowledge and as such is an autonomous way to God. Farther, God is known not by the intellectual intuition, but by the intuition of the will, that is through the effort of love, which is free from coercion, including coercion of evidence, so in this sense, it is autonomous (Hessen 1931, 287-288; Hessen 1968a, 129).

The key concept of Kant's philosophy - the concept of autonomy (freedom) - is treated here as a fundamental category depicting the total transcendence of God (and thus also goodness) to human cognition. In this way, the concept of autonomy becomes the basic determinant of via negativa used by negative theology, which seeks to capture the infinite (absolute) transcendence of God over a man and over the world through the negation of human finiteness ${ }^{22}$. It needs to be mentioned in this context that the issue of human freedom plays a key role in Byzantine theology, mostly with regards to the doctrine of salvations. Salvation - understood throughout Eastern Christianity as theosis - remains a work of divine love occurring within the world. This work can only take place because man remains completely free towards God. Man must fully voluntarily accept and consent to God's work. On the one hand, Byzantine theology acknowledges the universality of salvation; on the other hand, it makes clear that this redemption, although intended and accessible to all through the salvific work of Christ, requires a fully voluntary, individual commitment on the part of man (not enforced by any external authority). No one can be saved by God if one does not voluntarily wish for this to happen (Meyendorff 1999, 163). It is this freedom that Hessen refers to as the autonomy of good, and he sees it as the basis of the ethics of responsibility derived from Dostoyevsky's work.

This ethics - as well as the good that is the ethic's condition and pinnacle - remains an ethics that is autonomous (independent) from any philosophical, religious or ideological assumptions. Even if, in a particular sense, this ethics can be considered religious ethics, it is an ethics that transcends the opposition between theism and atheism. Freedom in the relationship between man and God also means freedom from knowledge (beliefs) about God's existence or non-existence. The intuition of the heart transcends these beliefs because it goes beyond all possibilities and factual states that we are able to think of and consider as data. The intuition of the heart is always expressed in creativity, i. e., in the creation of something completely new, which was not previously given even as a possibility. Only through such creative action the man can be truly free. Citing Bergson's viewpoint expressed in Essais sur les donées immédiates, ${ }^{23}$ Hessen states:

${ }_{21}$ Hessen refers here to Dostoyevsky's notes made by him when working on his last published novel Die Urgestalt der Brüder Karamasoff (Dostoyevsky - Komarowitsch 1928).

22 The relationships linking Hessen's thought with the tradition of negative theology have been discussed in: Wieczorek 2005, 103-110.

23 Authorized English translation: Bergson 1913. 
Bergson was right claiming that the freedom of will at its highest tension is not a choice between existing, and ready to use paths of doing things, but rather it is the creation of a new path that has not existed before. The moral act of this creative freedom often consists of finding a way out of a situation from which - it would seem - there is no way out. It doesn't mean choosing from the many easily accessible and banal resolutions, but rather it is a decision that creates the new resolution (Hessen 1968c, 306).

Of course, it is not the case that human daily moral practice is always based on moral creativity. On the contrary: this practice needs established, comprehensible, schematic patterns of conduct, without which it would be very difficult for a person to function. Hessen has no intention of denying this. He stresses, however, that all such patterns, (which are adopted by an individual during the process of socialization), do not constitute morality in the strict sense of the word, but are rather patterns of our legal actions. Legal norms differ from moral norms as they are mediated by concepts (discursive knowledge). Thus, their fulfilment requires far less willpower than the fulfilment of moral norms. Hessen writes:

In morality, duty is pure and direct, while in law it is obscured and diminished, as a result of a network of concepts (reasoning) with a logical structure that is imposed upon it. It is an intellectualized duty, that has been filtered through the prism of theoretical knowledge (logical regularity) (Hessen 1968c, 300-301).

The law tells us how we should behave so as not to violate legal norms. In the case of moral duty, we have no such knowledge. We have to act on our own responsibility. The very fact that we are able to capture the legal obligation by means of concepts leads to this duty only being applicable to standardized actions and situations, i. e., those that can be repeated. As Hessen expresses it:

A legal duty is not a bespoke garment specifically for an individual person, but a readymade, standard garment made for the average person (Hessen 1968c, 312).

The law, while remaining a kind of 'minimum of morality' (Hessen 1968c, 312), ${ }^{24}$ diminishes moral duty, adapting it to the requirements of an average man. However not only that, it also creates social conditions by which human creativity, which is the only one able to meet moral duty, becomes possible at all. The discursive knowledge (theoretical wisdom) that underlies the legal system is able to capture and constrain the various forms of violence that occur in social interactions. Legal norms entail the possibility of coercion against those who do not comply with these norms. Legal coercion is not just pure mistreatment, since every application of the law requires rational justification. Indeed, even the most correct functioning of legal norms cannot in the slightest degree substitute for moral creativity, but it can remove obstacles that stand in its way (Hessen 1968c, 313). In other words, the social space in which free human creativity - including moral creativity - exists is

24 This description Hessen took from Vladimir Soloviev. Hessens philosophy of law in the context of Russian tradition of legal liberalism has been analysed in detail in the book by Andrzej Walicki (Walicki 1992, 404-470). This author writes (Walicki 1992, 453): "From Soloviev, Hessen took the conception of law as the minimum of morality but interpreted it differently. By the minimum of morality he did not mean that the scope of law is less; on the contrary it is broader because many laws, such as traffic rules or different administrative regulations, are morally indifferent. Soloviev's definition is true if minimum is understood not as lesser scope, but as lesser intensity." 
possible thanks to the law. The moral autonomy of good thus presupposes the discursive (based on conceptual knowledge) autonomy of the law and cannot be achieved without $\mathrm{it}^{25}$.

In arguing for this kind of discursive autonomy of morality, Kant, according to Hessen, demonstrated the possibility of application of a system of legal norms rather than possibility of application of moral duties (Hessen 1968c, 301-302). Nevertheless, Kant's approach to the issue of autonomy remains valid precisely in the realm of law. The moral autonomy of good, that allows for creative moral practice, needs legal autonomy as its dialectical counterbalance. Only in this dialectical tension can the ethics of responsibility be realized in its concrete form.

Consequently, the outlined relationship between law and morality allows the whole issue of virtue ethics to be seen in a new light. This is an interesting issue, primarily because since the 1980s, there have been attempts to demonstrate the relevance of this ethics to contemporary moral reflection. These attempts have sparked widespread debate. The issue of the creative dimension of human morality and the indispensable relationship of the creative moral practice to the legal system, although in Hessen's analyses comprise the key problem of the moral reflections, have not yet been properly considered in the contemporary discussions on virtues theories. This issue, however, goes far beyond the framework of this article and needs to be addressed in the future.

\section{REFERENCES}

Augustinus, Aurelius. 1841-1865. S. Aurelii Augustini Opera Omnia. In Migne, Jacques Paul (ed.). Patrologiae Latinae Elenchus. Paris. http://www.augustinus.it/latino/index.htm.

Bergson, Henri. 1913. Time and Free Will: An Essay on the Immediate Data of Consciousness (trans. Pogson, Frank Lubecki). London.

Dostoyevsky, Fyodor. 2009. The Brothers Karamazov (trans. Constance Garnett). New York. http:// www.gutenberg.org/files/28054/28054-h/28054-h.html.

Dostoyevsky, Fyodor [Fedor Dostoevskij] - Komarowitsch, Wassili. 1928. Die Urgestalt der Brüder Karamasoff. München.

Folkierska, Andrea. 2005. Sergiusz Hessen - pedagog odpowiedzialny. Warszawa.

Grant, Alexander. 1885. The Ethics of Aristotle. Vol. I. London.

Gurvitsch, Georges. [Gurwitsch, Georg]. 1924. Fichtes System der konkreten Ethik. Tübingen.

Gurvitsch, Georges. 1932. Idée du droit social. Notion et système du droit social. Histoire doctrinale depuis le XVIIème siècle jusquà la fin du XIXème siècle. Paris.

Gurvitsch, Georges. 1940. Eléments de sociologie juridique. Paris.

Guthrie, William Keith Chambers. 1981. A History of Greek Philosophy. Vol. VI. Aristotle an encounter. Cambridge.

Hessen, Sergius. [Giessen, Sergiei .Iosifovich]. 1928. Tragedija dobra v „Bratjach Karamazowych Dostoevskago". In Sovremennyje Zapiski 35, 308-338. http://emigrantika.imli.ru/ news/7-sovremen.

Hessen, Sergius. 1929a. Die Tragödie des Guten in „Brüder Karamasoff“. Versuch einer Darstellung der Ethik Dostojewskis). Der Russische Gedanke 1, 63-80.

Hessen, Sergius. 1929b. Idea dobra w powieści „Bracia Karamazowi“. Z zagadnień etyki Dostojewskiego. In Przegląd Współczesny 28/82, 186-197; 28/83, 478-491.

Hessen, Sergius. 1929c. Der Kampf der Utopie und der Autonomie des Guten in der Weltanschauung Dostojewskis und Solowjows. Die pädagogische Hochschule. Wissenschaftliche Vierteljahrsschrift des Badischen Lehrervereins 1, 247-317.

${ }_{25}$ Compare also: Walicki 1992, 465. 
Hessen, Sergius. 1930. La lutte entre l'utopie et l'autonomie du bien dans la phielosophie de Dostoîevski et de Vl. Solov'ev. In Le Monde Slave 2, 224-250, 4, 41-58, 7, 19-38, 8, 186-201.

Hessen, Sergius. [Giessen, Sergiei Iosifovich]. 1931. Bor'ba utopii i avtonomii dobra v mirovozzrěni Dostoevskago i Vl. Solov'eva. Sovremennyje Zapiski 45, 271-305, 46, 321-351. http:// emigrantika.imli.ru/news/7-sovremen.

Hessen, Sergius. 1952. Le virtù platoniche e le virtù evangeliche. (trans. Mirecka, Hanna - Volpicelli, Luigi). Rome. [Second edition: Rome 1978].

Hessen, Sergius. 1958. Dritto e morale. In Hessen, Sergius. Diritto e morale. I diritti dell'uomo nel liberalismo, nel socialismo, nella democrazia, nel comunismo. (trans. Angle, Italo Carlo). Rome, 7-68.

Hesssen, Sergius. 1968a. Walka utopii i autonomii dobra w światopoglądzie Dostojewskiego i Sołowjowa. (trans. Walicka, Maria). In Walicki, Andrzej (ed.). Hessen, Sergius. Studia z filozofii kultury. Warszawa, 107-193.

Hesssen, Sergius. 1968b. Cnoty starożytne a cnoty ewangeliczne (Uwagi o podstawach etyki starożytnej i nowoczesnej). In Walicki, Andrzej (ed.). Hessen, Sergius. Studia z filozofii kultury. Warszawa, 194-268.

Hesssen, Sergius. 1968c. Prawo i moralność. In Walicki, Andrzej (ed.). Hessen, Sergius. Studia z filozofii kultury. Warszawa, 269-313.

Kant, Immanuel. 1903 ff.. Kant's Gesammelte Schriften. („Akademieausgabe“). Berlin.

Kant, Immanuel. 1999. Practical Philosophy. (trans., ed. Gregor, Mary J...). In Guyer, Paul - Wood, Allan W. (eds.). The Cambridge Edition of the Works of Immanuel Kant. Cambridge.

Kant, Immanuel. 2001. Religion and Rational Theology. (trans., eds. Wood, Allan W.- di Giovanni, George). In Guyer, Paul - Wood, Allan W. (eds.). The Cambridge Edition of the Works of Immanuel Kant. Cambridge.

Kukuła, Elżbieta. 1997. Związki etyki i pedagogiki w myśli Platona i Sergiusza Hessena. Na marginesie tekstu Sergiusza Hessena „Cnoty starożytne a cnoty ewangeliczne”. In Rutkowska, Halina (ed.). Filozofia wychowania Sergiusza Hessena. Warszawa, 172-180.

Meyendorff, John. 1999. Byzantine Theology. Historical Trends and Doctrinal Themes. New York. Natorp, Paul. 1904. Sozialpädagogik. Theorie der Willensbildung auf der Grundlage der Gemeinschaft. Stuttgart.

Plato 1903. Opera. In Burnet, John (ed.). Platonis Opera. Oxford.

https://www.perseus.tufts.edu/hopper/text?doc=Perseus\%3atext\%3a1999.01.0167.

Plato 1991. The Republic of Plato (trans., intro., notes Bloom, Allan). Chicago.

Plotinus. 1856. Opera. In Kirchhoff, Adolphus (ed.). Plotini Opera. Vol. 1-2. Lipsiae. https:// archive.org/details/plotiniopera00plgoog/page/n1/mode/2up.

Raphael's fresco. Cardinal and Theological Virtues (virtual gallery of the Musei Vaticani). https:// www.museivaticani.va/content/museivaticani/en/collezioni/musei/stanze-di-raffaello/stanzadella-segnatura/virtu-cardinali-e-teologali-e-la-legge.html.

Scheler, Max. 1972. Ressentiment. (trans. Coser, Lewis B. - Holdheim, William W.). New York.

Walicki, Andrzej. 1992. Legal philosophies of Russian liberalism. Notre Dame.

Wieczorek, Zbigniew. 2005. Filozofia wszechjedności Sergiusza Hessena. Kraków.

Wikipedia 2020. Cardinal and Theological Virtues (Raphael). https://en.wikipedia.org/wiki/ Cardinal_and_Theological_Virtues_(Raphael).

Wind, Edgar. 1937 - 1938. Platonic Justice Designed by Raphael. In Journal of the Warburg Institute $2 / 1,69-70$. 
Assistant professor Wojciech Hanuszkiewicz, PhD.

Pedagogical University of Cracow

Department of Philosophy and Sociology

ul. Podchorążych 2

30-084 Kraków

Poland

wojciech.hanuszkiewicz@up.krakow.pl

ORCID: 0000-0003-0117-5964 